\title{
Comendo com Txai, comendo como Txai. A sexualização de relações étnicas na Amazônia comtemporânea
}

\author{
Cecília McCallum
}

RESUMO: Este trabalho discute construções de identidade social do "índio brasileiro" no Acre, entre 1983 e 1991. Tendo como foco os Cashinahua e suas relações com organizações de apoio pró-indígenas, procurase analisar como conceitos e práticas que geram sociabilidade foram empregados ou negados nesse contexto social. Nesse propósito, é feito um esboço da forma assumida pelas relações interétnicas na região. Trata-se de entender as relações entre desigualdades no contexto sócio-político e mudanças nos construtos de gênero e sexualidade em situações interétnicas

PALAVRAS CHAVE: relações interétnicas, sociabilidade, sexualidade, gênero, organizações não-governamentais, Cashinahua, Amazônia, Brasil. 


\section{Introduction ${ }^{1}$}

This paper concerns the evolving relationship between two small groups of people, one made up of 'white Brazilians' and the other of 'Brazilian indians'. Each are ascribed and ascribe the other radically distinct identities. The paper attempts to see how the aspects of each group's discursive and social practices that concern social identity and difference come together in the socio-economic and political setting of contemporary Acre. It argues that they are forced to meet at the point where real, personal identities are constituted and that this process involves the redefinition of gender in terms of sexuality.

Each of the identities in question is discursively forged using sets of categories and concepts that have lengthy and often separate histories. The crucial conditioning factor for the constitution of each identity is its relation to representations of 'the Other', including, at many historical moments, oppositional relations to representations of each other. Thus, an identity as 'Brazilian' (of whatever colour, class or gender) is invariably built both out of and against the category 'Indian' (McCallum, 1995; Ramos, 1991; Skidmore, 1974). Social relations between indigenous and non-indigenous peoples in Brazil, in myriad historical and political contexts, are at once framed by this specific discourse of otherness, and at the same time endlessly rework and add to it. Similarly, an identity as 'True Human', as the majority of indigenous peoples in lowland South America denominate themselves, takes as axiomatic that real humanity comes into being through a series of complex social interactions with beings belonging to the category non-humanity (among which 'Brazilians' are often counted).

Anthropological and other discussions of alterity and identity tend to belong to one of two tendencies: Either those that operate within a narrowly ethnographic set of references; or those that deconstruct 'Western' or 'Euro-American' concepts and values thus distorting 
analysis and sustaining inequalities. The ethnography of lowland South American peoples is a rich field containing vibrant analyses of the former kind ${ }^{2}$. In the latter case, since South America and especially its natives have played a prime role in European constructions of the 'Primitive Other', a number of studies have been able to deal with the history of representations of native Americans ${ }^{3}$. Such analyses belong to a growing body of literature (within literary studies, culture studies, history of science, of ideas, of art) that analyse the ideological fields of primitivism and modernism in relation to race, class and gender ${ }^{4}$.

We know from both the strictly ethnographic and the more reflexive literature on identity and alterity that neither the indigenous American nor the Euro-American sets of ideas, symbols and practices about 'the Other' operates in terms of simple and exclusionist dichotomies. Both systems involve theories of time and process whereby the Other, or aspects of her/him, may be progressively incorporated in or excluded from the self. Such theories are closely linked to questions of power. The relationship between the Self and the Other takes its dynamic from processes of domination or of resistance. At one extreme the Other is a being to be conquered in the pursuit of an adequate social identity. At another moment that same Other is a being to be transformed into 'the same', so that conquest is no longer necessary. Importantly, the construction of gender and of sexuality are recognized to be primordial sites for such symbolic construction of the Other in a field of power (Haraway, 1989; Torgovnick, 1990; Kulick \& Willson, 1995). Yet in studies of inter-ethnic relations in Brazil, the importance of gender is rarely recognized.

Anthropologists have rarely documented the form sexual relations between distinct ethnic groups take ${ }^{5}$. This paper seeks to redress the balance to some extent, since it offers some comments on sexual relations between indigenous peoples and mainstream Brazilians in Acre. It cannot pretend to do more than suggest the importance of 
notions of gender and discourses about sex in interethnic relations, however, since these were never primary foci of investigation during fieldwork. What is more, the discussion is lopsided: My data on Cashinahua gender, sexuality and personhood is more fluid than I can make my comments on the pro-Indian Brazilians and Brazilian society more generally. Yet the paper is able to show, despite the lapses, the indubitable centrality of gender and sexuality in the inter-ethnic scenario.

In the paper, I ask what it means, for contemporary indigenous peoples in Acre, to assume an identity as 'Brazilian indian'? How do they go about doing so? This paper explores the issues involved in this process for one group of indigenous people, the Cashinahua young men and leaders who since the late 1970s have spent more and more time in urban centres in Brazil. To do so it offers some ethnographic comments on the people with whom these men interact most closely there, namely Brazilian professionals working in pro-Indian support organizations. It discusses interethnic relations in this area of Brazilian Amazonia before moving on to an analysis of processes of social identity constuction. It documents social theory and practice both among the Cashinahua and in the context of their relation with pro-Indian activists, examining notions of personhood, kinship and sexuality ${ }^{6}$.

The backdrop of this discussion is the following question: How does a dispersed group of people, few in numbers, with a non-essentialist cultural heritage allied to an egalitarian political philosophy and a deep fascination with difference as the basis of all that is social, meets with the massive presence of a population whose dominant philosophical heritage is rooted in a politics that emphasizes hierarchy and subordination over complementarity and equality. The paper argues that in the unequal situation in which this interaction takes place and that is a focus of this paper - gender relations and sexuality have become a means whereby the language of unequal difference has become part of the vocabulary of indigenous people in the city. 


\section{The Context}

The state of Acre was the home of Chico Mendes. It is still the arena of struggle for many non-governmental organizations (NGOs) mainly based in its capital city, Rio Branco. Supporting and directing the political activities of either indians or rubber tappers, the NGOs have been successful both in capturing resources, organizing bases in the city, vocally supporting their rights in the local and national political context, effecting economic, educational and health projects in the rural hinterland and also notably in drawing international attention and action to the defence of their causes ${ }^{7}$. Within this highly charged and conflictive arena the NGOs are often at odds with each other and distanced from the local communities whose interests they defend. This political minefield reflects the diverse origins of their members, the distinct needs of urban and rural dwellers, as well as conflicts of interest, for example in the competition for resources from international or national funding agencies.

The number of NGOs representing indigenous rights outnumbers proportionately, those speaking for the rubber tappers. In Rio Branco the following were in operation during my last visit:

- CPI-Acre (Comissão Pro-Índio) - Pro-Indian Commission of Acre. - UNI-Norte (União das Nações Indígenas-Norte) - (Local branch of Union of Indigenous Nations)

- CIMI (Conselho Indigenista Missionário) - Missionary Advisory Council.

- Lutherans

- At the Fundação Cultural do Acre an office and a teaching area was made available to other individuals working for indian rights.

Of Acre's population (an estimated 320,000 in 1986), just under roughly three percent are classified as indigenous peoples (about 8,500 to 10,000$)$. Of these the largest groups are the Cashinahua (self- 
denomination 'Huni Kuin') and the Kulina, numbering about 2,500 each, who belong to two distinct language groups - Panoan and Arwakan. The other indigenous peoples are either Panoan speakers Arawakan, with a fair proportion now bilingual or monolingual in Portuguese $^{8}$. Of the non-indigenous Acreanos (the 'Cariú'), the majority are the descendants of male Northeastern 'retirantes' (emigrants fleeing from the droughts and famine) who are locally known as 'cearenses'. Some are miscegenated through local indigenous women. The rest of the non-indigenous population is made up of more recent immigrants, the majority 'soldados de borracha' (soldiers of rubber) who came from the Northeast in the 1940s and the rest colonists from or via Southern Brazil in search of land to farm? 9

Acre's history has been shaped by violence against indigenous peoples and by the production of rubber. Where the indigenous people survived 'first contact' epidemics, they were frequent targets of correrias (planned massacres). The lucky ones either fled upriver or became the protected workers of a small number of bosses, who repressed rituals, destroyed leadership systems and split up extended families into smaller units more conducive to the system of rubber production. The area was only settled by non-indigenous peoples after 1860 , and until the 1970s the dependency structure of rubber production based on 'aviamento' and debt bondage predominated in rural areas. The upsurge of speculation in land in the early 1970s forced many rubber tappers off the land, swelling the urban population. But the majority of indigenous people were able to stay in rural areas. By the end of the 1970s they began to lay claim to their lamd rights and struggle against control by non-indigenous bosses, in parallel with the independent rubber tappers around Xapuri and Brasileia, who struggled against the hostility of local medium scale ranchers and the political elite in Rio Branco.

Outsiders were important in stimulating resistance to expulsion from the land by speculators. Terri Aquino, an Acreano anthropologist, set 
up the Pro-Indian Commission which acted mainly in Cashinahua areas in the Jurua river area, whilst the Catholic Church and the Lutherans attempted to organize the Kulina and some other population groups in the Purus river basin. Given the collapse of the rubber economy, resistance to indigenous claims to land was relatively weak, since most indigenous areas were located far upriver away from the slowly expanding road system and were therefore less attractive to the speculators. Progress was made with difficulty. But final demarcation, supposedly guaranteeing the land, proved near impossible to achieve. Resistance and inertia up to the highest levels of bureaucracy and government in Brasilia proved too powerful.

During these years (1970s to 1990s) indigenous leaders had to make frequent visits to the city of Rio Branco and further afield to Brasilia in the struggle for land rights, for control of the local FUNAI agency (National indian Foundation, the government organ responsible for indians), for economic projects allowing independence from local white bosses and itinerant river-traders ${ }^{10}$. They also fought for education and health projects for their areas. After some early trials starting in the late 1970s, the CPI-Ac (Pro-Indian Commission of Acre) set up a state wide education programme in 1984, bringing young indigenous people (mainly men and mainly Cashinahua) to the state capital each year for training courses lasting up to four months each year. These 'monitores' would then return home to run alfabetization classes in schools monitored by their teachers. At this time the CPI-Ac also set up a health programme aimed at training barefoot doctors. A health project, funded by a British agency, was also run by the local UNI (which was directed by indigenous leaders). Different in focus, this aimed to send an indigenist doctor at regular intervals to certain areas to train in situ, to conduct community education in health issues and to treat the sick. UNI opposed training courses based in the city, unlike the CPI. CIMI sponsored a doctor with similar aims to work in the Purus area. 
Meanwhile both NGOs and the indians themselves made use of the precarious government-run facilities in Rio Branco. Here a FUNAI-run 'Casa do Indio' (House of the indian), surviving on a day-to-day basis all through the 1980s and into the 1990s, served as a base for sick and healthy indians alike in the worst of sanitary conditions. From here the ill were taken daily by a FUNAI nurse to enter the public health system, to be hospitalized or not depending on their condition and the availability of beds. By the end of 1980s tuberculosis was dramatically on the rise and in one indigenous area close to the BR-364 (the road linking Acre to the rest of Brazil) malaria had become the major cause of mortality and morbidity was near $100 \%{ }^{11}$. In 1993 cholera struck the Purus and an estimated sixty people died in the Peruvian headwater region ${ }^{12}$.

\section{Inter-ethnic relations in Acre}

The first modern anthropological studies in Acre in the 1970s found a clear demarcation into ethnically distinct categories (Aquino, 1977). The main contrast was between 'whites' and 'indians' ('brancos' and 'índios'), as it still was in the early 1990s. The non-indigenous settlers were designated 'cariú' as opposed to the indigenous peoples who were 'caboclos'. If born in Acre the cariú were designated 'acreanos'; if immigrants from Northeastern Brazil, 'cearenses'. The cariú were composed phenotypically of a mixture of brown and white with very few blacks. They ranged in appearance from pure indigenous, AfroBrazilian to blonde and blue eyed, with the majority somewhere in between. The urban middle classes tended to be whiter and usually were referred to as 'brancos' ('whites') rather than cariú. Otherwise, other Brazilians from Southern Brazil were known as 'paulistas' whatever their provenance. In general, one heard the term 'whites' used to refer to non-Indians in general (whatever their skin colour) and the term 'indian' employed in contradistinction. Related to this categorization, 
Revista de Antropologia, São Paulo, USP, 1997, v. 40 nº 1.

with its racial overtones, were a number of other conceptual oppositions, such as civilized/savage, christian/pagan, adult/infantile and human/animal.

\section{(A) The rural context}

How were these categories related to the situation in the rural areas and expressed in relations between local tappers and neighbouring indians? The following account of the Cashinahua case is mostly based upon Cashinahua exegesis and my own experiences in the field.

Cashinahua social interaction with their neighbouring Cariú tends to be amicable but latently hostile. Thus when local Cariú visit a village they are neither fed, nor invited into people's houses. Nor are they addressed by any term of kinship, except perhpas 'Compadre' or 'Comadre'. The most usual form of address is by use of their Christian names. Meat and fish are hidden. "Do not give them any caissuma (a drink made of corn and peanuts) - they won't drink it anyway" people say. Likewise in day-time visits to non-Indian settlements, the Cashinahua expect not to be fed or even offered the traditional cafézinho (sweetened coffee) unless a relationship of friendship exists. In general one can say that during the period I spent in a local community a system of mutual avoidance where feasible characterized local Cashinahua/Cariú relations.

Behind this latent hostility lies a history of rank prejudice, detailed by Aquino (1977). The Cariú considered indians to be "dirty", "lazy", "children", "not human", "cannibal" and so on. Aquino shows how this perjorative classification was the justification for discriminating against them - paying less for their rubber, their cattle or their labour.

My own data corroborates Aquino's and suggests continuity between the 1970s and the 1990s. I found on numerous occasions that these values continue to influence Acreano attitudes toward the indians, as illustrated by the following story: 
During a voyage to the Purus in 1990, before leaving the town of Manuel Urbano on the canoe trip upriver, I began to hear stories of a "beast" that had been seen on the road connecting the town Southeast to Rio Branco. It was very tall and hairy and had left jaguar like footprints. Glimpsed by a terrified roadside dweller, it had tried - it was said - to attack or grab her children before running into the forest from whence it had come. "What was it"? people asked. "An indian"? And indeed on my trip upriver, as I and my Cashinahua friends stopped off for the night in tapper houses, I was asked several times about the beast and whether I thought it was an indian. My interogators did not appear to find it strange that most of their guests for the night were indians.

For the rural Acreanos, people are categorized according to a moral continuum that runs from savage/animal to civilized/human. Thus these Cariú who inquired about the beast would affirm that the Cashinahua were "good" indians, already civilized. The story illustrates fear and prejudice, but the fact that questions were addressed to me in the presence of Cashinahua guests is important. Most of the Cariú classified me as the 'Indians' teacher' or the 'girl from FUNAI' ('moça da FUNAI). My function was to civilize. indians, then, are above all 'civilizable'. They may become 'like us' given the correct circumstances. Their original condition as beasts and savages is not based on inherent biological qualities, but rather on context. The indian in social isolation in the forest is very different from his descendant who is apparently at home in the company of the Cariú. Attributed monstrous bestiality at one extreme, then, at the other indians are able to become transformed into human beings by the civilizing process.

Likewise the Cashinahua recognize differentiation within the class of Cariú. Certain Cariú are "friends". Thus on trips upriver certain houses were always possible stopovers because their owners were "gente boa" (good people). Nevertheless I was usually the one delegated to request shelter for the night. Sometimes in less friendly houses shelter was granted but with obvious coldness towards the Cashinahua. On one occasion the owner arrived with a load of 
watermelon from his riverbank garden but neglected to offer any to his guests. At crack of dawn we arose, crossing over the beach on our way to the canoes, hastily robbing the ripe watermelons encountered on the way - a sweet revenge indeed!

It was sometimes considered prudent by some Cashinahua to ask local Cariú to be the godparents of one's children, though these relationships rarely seemed to lead very far. More often Cashinahua preferred to ask other Cashinahua. At parties and football tournaments local Cariú might be asked to attend or compete, so that although on a daily basis mutual avoidance was the rule, occasional more formal gatherings might bring the two groups together. However, these peaceful interactions did not stop the occasional outburst of tension or hostility, mainly when some individual Cariú invaded indian land to hunt with dogs or fish with commercial nets (McCallum forthcoming a).

\section{(B) The urban context}

In the city, where the majority of the residents of poor districts were originally rural dwellers, prejudice against indians remains strong. Here the forms of prejudice developed 'on the frontier' meet other forms developed in contexts such as the national media or in the geo-political ideology of the military dictatorship ${ }^{13}$. Attitudes were not always negative. Newspapers printed stories of land conflicts, occupations ofthe local FUNAI office, the dreadful state of the 'Casa do Indio', tuberculosis and malaria epidemics, and a weekly column written by a well-known anthropologist about the goings-on of Acre's indigenous people. Yet the respected historian Tocantins could restrict his comments in his small treatise on modern Acre to the absurd assertion that only a small and negligible tribe of cannibal indians were to be found in the interior of the state (Tocantins, s.d.).

Indigenous peoples did not form a large community in Rio Branco, although their presence through the 1980s became more and more 
visible. No local community developed, with residents scattered in invididual houses located mainly in different low-income districts throughout the city. These people came from a wide variety of groups - especially Yaunawa, Apurinã, Yaminahua, and Cashinahua. By 1990 a group of Yaminahua came each dry season to set up a camp each summer under the bridge in the centre of the town as a base for begging (and some alleged prostitution). Other indigenous people, including Yaminahua, were greatly annoyed by the ill repute this camp brought. Temporary residents from all nations stayed in the 'Casa do Índio' or else in the 'Fundação Cultural' if participating in one of the CPI's courses. Every day small groups could be seen walking out along the main road into town from the Casa do Indio, heading for political meetings, for FUNAI, UNI or the Bishop's palace (where CIMI was based) in order to sort out problems, to visit sick relatives in hospital, to sell handicrafts or to buy or beg fish or bananas at the nearest market. Generally only the leaders and some of the student teachers had enough money to pay the bus fares or buy food. The indians excited some curiosity but were not numerous enough to elicit any other reaction, as far as I am aware. Since much of the population of Rio Branco consists of Cariú ex-tappers and their children, one can suppose that attitudes to the indians are basically similar to those encountered in the rural context. The matter awaits further investigation.

In conclusion, we can say that the history of interethnic contact in Acre produced a situation where differentiation between 'white' or 'cariu' and 'indian' or 'caboclo' maintained itself through the period. The construction of ethnic identities adapted to changing demographic, political and economic circumstances. But at no stage did the category of 'indian' begin to break down or the major indigenous peoples become assimilated into the Cariu population. A remarkably large proportion retained their language, their cuisine, their marital systems and kinship terminology. This resistance will no longer surprise students of 
contemporary Amazonia but continues to conflict with popular perceptions of 'interethnic contact' ${ }^{14}$. In some groups cultural continuity is highly visible. The Kulina are a case in point: They have refused even apparent cultural assimilation and the shamans are highly visible and feared by other peoples, indigenous and non-indigenous alike. The Cashinahua on the other hand are enthusiastic about many facets of Brazilian consumer culture and are often keen to acquire medicines, industrial products and even food. Many are proficient in Portuguese and innumerable aspects of Cariu culture. A person unaccustomed to Cashinahua mores might easily reach the conclusion that they are well on the way to 'acculturation'. In fact the search to understand the 'Nawa' (as the 'whites' are denominated by the Cashinahua) and an intelligent desire to dominate their form of politics has motivated much of their participation in white-led education projects.

The persistence of ethnic categories and the maintenance of group boundaries obviously takes place in a changing political, economic and demographic climate. Factors influencing these continuities can be pinpointed in political and economic contexts as I shall show below.

However, the crucial determining factors must be sought at the level of social organization within the groups, and social relations within and between them. Thus, in order to understand why categories persist, how social identities evolve and boundaries constantly reemerge, one must take into account the construction of kinship and the notion of the person.

\section{The notion of personhood and the construction of identity}

\section{(A) The Cashinahua}

Pre-contact concepts of otherness and forms of relations with others have developed in the context of modern Cashinahua history ${ }^{15}$. The 'Nawa' 
(Foreigners) are both a source of goods and knowledge essential to the continuation of good social living in Cashinahua communities, and also a source of disease and destruction. Rich in covetted commodities, they are usually miserly, thieving and angry in Cashinahua eyes - all qualities to be despised in real human beings. Good for trading, they are bad for living with and especially for marrying. Thus the social division between Cashinahua and Nawa, like that between Cashinahua and other indigenous peoples remains very clear.

However one must be careful how one understands the attitudes and theories that underlie this division. The Cashinahua, whilst locked in a profound intellectual engagement with alterity as the basis of social theory are by no means dualists. The conceptual oppositions of indigenous Amazonian Societies are exactly predicated on the possibility and indeed necessity of mutual interpenetration and even of the periodic and graduative vanishing of differences ${ }^{16}$. Such vanishing, however, must always exist alongside the constant recreation of differences - for example in the separation of the living from the dead. In the case of the Cashinahua, this takes the form of ambivalent exclusivity in social practice, whereby the other (in this case the whites) is excluded from the domain of sociality, but that exclusion always contains the possibility of eventual and progressive integration. Before showing what practical form this possibility of the overcoming of difference has taken in recent times, it is necessary to delve more deeply into Cashinahua social practice itself.

This is important because it will allow an understanding of how Cashinahua men come to approach social relations with whites, especially in terms of evaluating their behaviour as more or less human, and more or less acceptable. Dependent upon this, relations of predatory exchange can give way to joking friendships centring upon the possibility of sexuality and eventually move on to the possibility kin ties being established. But this progress must take place under 
Cashinahua terms, so that what is feasible in relations between them and "good" whites is the "domestication" (dua wa-) of the whites and transformation into potential parents of Cashinahua children.

Insofar as one can determine "continuity" in culture and social organization through intense historical change, the Cashinahua form of sociality based on day-to-day living practice is the nub of continuity with the past (McCallum 1989). Based upon a specific theory of personhood, the cycle of daily production, circulation and consumption gives force and coherence to kin-based communities. Gender acts as pivotal in the cycle. Thus, it is normative for men to go out of the local community into other spaces - such as the forest or the city - to "fetch" game or goods via predation and exchange. Exchange, be it economic or cultural, with non-Cashinahua persons should reinforce sociality within the community ${ }^{17}$. Women, on the other hand, create a productive and reproductive space at home. But this is not 'domestic' production: Each gendered sphere of action is mutually constitutive of the social process in interaction with the other. Importantly, men and women in complementary production create kin - their children - through the circulation and consumption of food and things. This is the axis of sociality. Body processes of all kinds are part of this social process rather than being the base out of and over which they are constructed. Proper food, transformed through the body, generates the strength to work and also to fabricate children. Children's bodies are formed and made to grow in a complex process through sex (whilst in the womb), feeding and formal and informal training. This 'making grow' eventually genders the children and makes them into proper persons - true 'Huni Kuin' (humans) - able to produce and thus exchange, give and 'make grow' in their own right (McCallum In Press; McCallum Forthcoming b).

The whole complex serves, among other things, to generate a strong sense of identity as Cashinahua in contrast both to other indigenous 
peoples and to the Nawa. Naturally, appeals to this sense of identity are relative and dependent on context. In one situation all Cashinahua are included as "human" and "one family"; in another only close kin and affines are included, whilst others are "not real" or even "already Nawa". Likewise the Cashinahua might include themselves and all other indigenous groups in the same category of "Indian" in certain contexts in opposition to "Whites". The sense of identity might be expressed in innumerable ways by the Cashinahua. Aesthetics: the ways of dress and beauty; Language: correct ways of speaking; Politeness; Body language; Religious rituals, myths and other "traditions"; healing systems whether shamanic or fitotherapeutic and so on. However the most important practical bases of identification centre upon kinship.

When two Cashinahua meet for the first time, each attempts to discover the others 'true name' (kena kuin). This will belong to a limited number of semi-secret names each belonging to one of eight sets which in turn belongs to one or other moiety. Marriage is moiety exogamous to a person belonging to a specified name set in a specific relationship with ego's. One acquires one's name from a same-sex grandparent or his/her same-sex sibling so that theoretically marriage is determined through kinship ties - and indeed the preference is for marriage with a $\mathrm{FZCh} / \mathrm{MBCh}$ - in other words bilateral cross-cousin marriage ${ }^{18}$. Thus, once you know what a stranger Cashinahua is called, you know what relation category in which to place her or him, and what corresponding address term to use. Thus "Raimundo Mendes Cashinahua", true name of "Sian" will instantly know that "Alfredo Nonato Cahinahua, true name "Bixku" (both of the Dua moiety) is Brother to him. The Cashinahua themselves recognize that this system sets them apart from other peoples, with the exception of the Yaminahua who also use a similar naming and terminology system.

Nevertheless the linguistic aspect of social interaction is only a part of the story: Names are only a start. The true test of humanity is not that one has a true name but how social interaction proceeds. In a 
Cashinahua environment this centres very much on food and sexuality. Generosity with food and the capacity to feed others (as well as be fed) characterizes the construction of proper sociality and therefore of kinship itself. It is not enough to be placed in a categorical relationship - that relation must be given content over time. Cashinahua visitors from afar expect to be well fed on arrival in a Cashinahua village. They also know that they will be asked for presents and often give away some treasured possessions that they have been unable to hide. If the visitor has come to stay, she or he will either marry with a resident of suitable category or eventually marry their children with them. Ideally marriage remains community endogamous, so that a condition for integration is co-residence.

One can abstract a sequence for the process of integration of outsiders. Thus initial hostility is replaced by the possibility of affinity that follows on from naming or recognition of the place within the relation system through names. If actual marriages are then arranged, they then imply the possibility of practical bonds of kinship being established over time. This is the process of constructing kinship, which receives its definitive expression through the appearance of children, in turn integrated into the naming system. As they grow up and produce properly Cashinahua grandchildren, the process is complete.

How does this social system encounter that of the neighbouring nonindigenous rubber tappers and that of the urban-based NGO workers? Here there is an interesting contrast. Whilst the Cariu have intermarried with Cashinahua in the past, they have never been integrated into the social circle defined initially by linguistic competence and the use of true names. The pro-indian activists on the other hand, are quickly named and encouraged to enter the domain of possible kinship through the use of the correct terms of address. Yet they rarely go beyond the first stage, that implying the possibility of sexual interaction and an affinal relationship, as I will describe below. 
Although there have been cases of inter-marriage between Cashinahua and the tappers, these tend to fail eventually and the Cashinahua partner returns to the fold and finds an indigenous spouse. Most cases known to me are of women who married out. Here, the children return with their mother and become Cashinahua and the father disappears. Alternatively, as has happened in the case of other indigenous peoples, the person leaves the community and becomes absorbed into tapper society, especially if marriage is concurrent with migration to an urban area. However, in the vast majority of cases Cashinahua jealously guard their children and ensure that marriages remain close at home with kin of an appropriate category. Marriage is rarely part of the inter-ethnic system.

However, the linguistic usages that have developed recently between activists within some of the NGOs and the Cashinahua encapsulate the possibility of affinity. The developing relationship, I would argue, is characterized by the ambivalent exclusivity peculiar to Cashinahua concepts of relationship with the Other, as we might expect. Yet it takes the form it does as much through the social forms adopted by the activists as from the initiative of the Cashinahua. This is what we might call the Txai complex.

Historically Cashinahua men would address potentially friendly male others, of whatever category, by the term 'txai' which can be glossed as 'brother-in-law' or 'male bilateral cross-cousin' ${ }^{19}$. Thus relations with foreign others contained the linguistic potential for affinity and eventual integration even prior to naming. Alongside this potential many of the behaviours associated with relations between potential brothers-inlaw were played out. Thus Cashinahua would joke with their foreign friends, in a style laden with sexual allusions and a masculine bravura. Such txais could become good friends and as the relationship progressed joking and companionship could become easy and relaxed. The system undoubtedly worked well when the majority of the Cashinahua's 
neighbours spoke related Panoan languages, before settlement by Brazilians. Txai was mutually intelligible as a form of address.

This usage has continued into present times. The Cashinahua of the Jordão began addressing the anthroplogist Terri Aquino by this term. He adopted 'Txai' as a form of address and relationship not only towards male Cashinahua but also all other male indians. Other activists and visitors associated with the CPI (which Aquino was instrumental in creating) have also adopted this term, including now women activists. Since other Cashinahua and Yaminahua also use it, it has become an essential part of the language of interethnic relations in Acre. So much so that after Milton Nascimento travelled with Aquino and other indigenists, indians and rubber tappers on the Jurua river, he called his next record Txai.

Although activists seen as friends by the Cashinahua are always given a 'true name', they very rarely learn how the naming system works and do not adopt the address terminology associated with it. This is because indigenists and anthropologists usually do not learn to speak Cashinahua or Yaminahua (seen as "too difficult"), unlike those who work with the Kulina (seen as "easier"). The common language used is always Portuguese. This means that from the Cashinahua point-ofview the friendly Nawa (those with true names) rarely acquire linguistic competence sufficient for greater integration into the social world of the Cashinahua and eventual socially correct in-marriage.

\section{(B) The pro-Indian Activists}

Who are the pro-Indian 'Whites' with whom indigenous peoples interact? Why do they not intermarry? Why if their political aims often coincide do their social worlds remain separate?

Individuals are drawn from all over Brazil to work for some time with indians in Acre or even to settle there. Others (the minority) are 
Acreanos. Most come from a middle class milieu and are of IndoEuropean extraction. A high proportion are women. These people tend to be specialists such as anthropologists, indigenists, nurses or doctors, to have higher education or to be in the process of working towards advanced university degrees. One may say that many of these proIndianists, together with other young people who come to Acre - NGO workers, journalists, students, biologists, ecologists etc. are motivated in part by romantic concepts about Amazonia, nature, and indians. However, any idealism is soon tempered with a good dose of pragmatism. Such romanticism in relation to indians and to Amazonia has deep roots in the Brazilian liberal tradition and in the construction of national identity ${ }^{20}$. Most Brazilians with school education have been exposed to specific images of 'the indian' which include both a romanticist tendency and a primitivist one. indians are portrayed both as the primitive and savage ancestors of modern Brazilians, who were necessaily 'civilized'; and as the early heroes of incipient nationalism, as they bravely sacrificed themselves in the struggle against the Portuguese (Rocha 1984). In edition to this largely standardized construction of the indian other, most Brazilians of the generations that work as pro-Indian activists have been exposed to the nationalist ideology of the military dictatorship, with its vision of 'opening up' Amazonia and civilizing it. Savage indians play an important role in this ideology, both as representatives or allies of the external other (foreign governments and mining companies), and as symbols of 'brasilidade' (Ramos, 1991; Arnt \& Schwartzman, 1992; McCallum, nda and 1995). More recently, a romantic vision of the indian as Nature's creature has been propagated in pro-ecology media. It is fair to suppose that all these sets of ideas and representations have affected the activists' pro-Indianism. In their circles it is also often allied to Leftist tendencies or, in the case of missionaries, the more radical methodologies of action such as liberation theology ${ }^{21}$. It should be 
noted, too, that young professionals might also find better job opportunities in Acre than in the more competitive markets of Southern Brazil. Most pro-Indianists, however, receive low incomes on the professional scale, so employment and income are motivating factors for the minority rather than the majority. Initial motivation lies rather in the pursuit of self-fulfillment, the search for an 'alternative' lifestyle, and political idealism.

The pro-Indian activists are 'on the move' from their social milieu of origin. In Acre, and especially on the upper rivers in indigenous areas, they are alone, distant from families, colleagues and friends. In their distancing from family, choice of profession, willingness to forgo comfort and live frugally in the forest, and above all in their approximation to indigenous people, the activists go against the current in Brazilian mainstream culture. In this sense they may be characterized as 'individualists'. For this reason, one must be careful not to overgeneralize in their respect - and indeed this is difficult given their diverse social and geographical origins and varying motivations. However, they do have in common a powerful sense of purpose in seeking to better the political circumstances and standard of living of the indigenous peoples. In pursuit of this aim, I argue, the activists construct a particular identity for themselves that is openly nationalist, and implicitly gendered and linked to class.

Unlike many (though not all) white or Cariú Acreanos, who have little empathy for indigenous peoples, most pro-Indianist activists foster a positive image of the indian. Their professional but also personal social identities are built upon their relation to this positively conceived 'indian'. Often they seek to shorten the social distance between themselves and the indians. This is signalled in many ways. Thus while Cariú will reject caiman as food, the activists will revel in it and many other dishes of indian cuisine. In this way a category, which I have arbitrarily labelled 'Pro-Indian Activist', comes to be 
constructed both out of the difference between the activists and the indians, but also out of that between the former and the Cariú. Thus it reflects the class differences between Cariú and activists.

When the activists travel to indigenous communities, they stay in their hosts' houses, share their food and participate to some extent in community activities. Generally only the CIMI workers and the Lutherans actually live for long periods in the communities, and engage in their own productive activities, such as planting gardens. When the indigenous people travel to the city, however, they are rarely able to stay with the activists, whose houses are too small and budgets too limited to put up the endless stream of needy visitors. This creates a serious disjuncture in the process of approximation between the two groups. We can illustrate this point more clearly by returning to the Cashinahua.

From the Cashinahua point-of-view, the activists are "good" for many reasons, such as their enthusiasm about Cashinahua culture and cuisine. But because they are not able to reciprocate hospitality in kind, they do not reaffirm the acceptance of their status as possible future kin through affinity. Simply put, if the activists do not feed and house the Cashinahua, they can never be part of the world of true sociality. They will never become the parents and grandparents of Cashinahua people.

\section{Interthnic relations in a field of social power}

This situation is reinforced by the social, economic and political context of interaction of 'whites' and 'indians' in the city ${ }^{22}$. Here, the indians experience both constant, if semi-suppressed, racism and also the effects of their financial, demographic, social, political and cultural weakness. Unequal relations are constantly constructed in daily interaction with whites. This is particularily true of the experiences of 
indian men in the city, because they are more likely to find themselves in a situation of competition or comparison with whites than are indian women. Women mainly come to the city when ill; men come for a variety of purposes. Indigenous communities tend to send young men rather than young women for the CPI's training courses, particularily in the Cashinahua case. Men are also more competent in Portuguese than women, on the whole. Most of the leaders who come to the city are also men. Hence the image of the 'indian' as generically male is reinforced, but nearly always in a situation where whites and indians are on unequal footing.

Activists interact most often with these men, in a situation of significant income differential. In general, whilst most of the former have fixed salaried jobs, indian teachers and barefoot doctors do so infrequently. Except for indians contracted by FUNAI, remuneration where it exists is comparatively derisory. The CPI was constantly attempting to better this situation, but according to one informant by 1994 the barefoot doctors still worked unsalaried. In 1991, during my last visit, they were directly dependent upon the doctor in charge of the CPI's health education programme for the occasional handout. To be in his good books, they were obliged to bend to the rules, not missing classes and arriving on time. The same was true of the teachers who, when absent at classes or reported to be inefficient in giving lessons back home, were threatened with dismissal by the activists who ran the CPI. As a result, in the very institution whose aim is to empower indigenous peoples and defend their rights, the indians were placed at the bottom end of a command hierarchy dominated by whites.

The structure of interaction with the indians in the classroom as in other urban contexts also leads to the construction of unequal difference between white teachers and indian students. Up to 1991, the classes for student teachers took a classic form. The white teachers stood at one end by the blackboard explaining and teasing responses 
out of the seated students, always using the Portuguese language. The indians were often asked for ideas and information, but the unspoken message in the process was that the whites were revealing truth and the indians were there to learn it. But they also learnt during these long months in the city to formally structure a hierarchical pedagogic situation of which social inequality was a fundamental part.

These forms of inequality are new to the young men. They hark back to the relationships prevalent some 20 years ago between Cariú bosses and the parents of this new generation in the production of rubber. But they operate in a very different context. For whilst the purpose of the bosses was to profit on the backs of indigenous labour, the purpose of the teachers is to free the indians from such situations of economic exploitation and political subservience. One must be careful to disassociate the avowed intents of these activists from the short-term effective outcome of their educational activities. Their purpose is to capacitate indigenous people to better defend their own interests, both political and cultural. To this end they involve the indians in the creation of 'cartilhas' (literacy textbooks), originally in Portuguese but more recently in indigenous languages as well. These textbooks and activities in the schools are intended to form a sense of Brazilian as well as indigenous identity. This is illustrated graphically by the CPI's work with the Cashinahua language. A two volume dictionary and grammar of the language had been compiled and published by North American SIL missionaries in Peru. However, it was ignored in the CPI's language programme. The directors particularily objected to the established orthography, based as it was on a mixture of Spanish and English conventions. They repeatedly told me that the orthography had to be Brazilian in basis.

A central aim of the CPI's education programme is to make their pupils into true 'Brazilian indians'. Indigenous leaders also actively construct an identity as 'Brazilian indian' in order to better lay claim 
to their legal rights. But for the indigenous leaders the category is largely part of a symbolic battle where the discourse of identity is adapted to suit their purposes (thereby one supposes not interfering with their own private sense of identity born out of life "back home" in the village). In contrast, the pro-Indianist activists use a less superficial concept of Brazilian identity. Their programme aims to strike at the heart of the person, grasping the intellect of their indian pupils and fashioning it as in a mirror of their own vision of "Indian-ness". If cultural repression played its part in boss-Indian tapper relations, cultural and intellectual transformation is the avowed intention of the educationalists. They expressly oppose the adherence to 'tradition' that they attribute to CIMI activists, for example, or to the conservative and 'exploitative' research activities of anthropologists ${ }^{23}$. In their view, tradition has its part to play, but only as an aspect of identity construction, controlled through the written word, through films made by indian pupils, and through the classroom ${ }^{24}$. 'Culture' is thus progressively rendered folklore ${ }^{25}$.

The CPI activists seek to establish 'modern' social ties with individual indigenous people, either as students, employees of the CPI run project, or in some cases as friends. The modernized Brazilian indian is in this context aware of his forebears' traditions, alive to the need to preserve their memory and conscious of the legitimation of his own identity that they effect. However, he also 'forward-looking', politically smart, distanced from the ignorance of the majority of his people, alive to a new world of cultural creativity and personal fulfillment. In relations with whites such as the activists, those few indian men who successully fit to this mould can surpass the ethnic and class barriers, finding success in middle class and artistic milieu both nationally and further afield, establishing friendships or even sexual relations. The next section attempts to come to grips with some of the issues involved in these relationships. 


\section{Interethnic relations and sexuality}

The domain of sexuality is crucial in the process of identity construction for indians as well as whites. Thus, indian men may use the language of Brazilian sexuality as a form of empowerment, as they come to experience their identity as 'Brazilian indian' more profoundly. The closer the grasp of urban mores and the more intense the relationship with Brazilian structures of social inequality, the more readily is the identity constructed as one of male potency and sexual presence, as I shall show. But while both may use sexuality as an aspect of identity construction, each bring very different understandings of sex and gender with them.

Whilst for the Cashinahua marriage and sexuality are closely linked (in that one's lovers should be potential marriage partners, real or classificatory cross-cousins), for the friendly whites sex and marriage are conceptually distinct. This distinction is particularily strong in relation to indians. Activists might view the Cashinahua as potential lovers but not marriage partners. Why is this so? Such affairs can be explained on several levels: Desire for the exotic Other may be among them. I focus here on their symbolic work in terms of race and gender in Brazil, suggesting the part that this might play in the construction of specific social identities.

In the case of white women, a love affair with an indian is particularily subversive of established sexual codes, even a form of transgression. Whilst white men can establish sexual liasons with black or brown women in Brazil without raising eyebrows, the opposite is more rarely the case. This well established cultural rule is especially strong in respect to indigenous men. A closer examination of the symbolic structures of public discourse about race and miscegenation reveal the profundity of meaning attached to this taboo. I have demonstrated extensively elsewhere (McCallum, nda 1995) that in 
Brazilian nationalist mythology, indian men's sexuality is necessarily effaced in the context of interethnic relations. white supremacy is expressed in the conquest of the indian women - the grandmothers of the miscegenated nation. Sex between an indian man and a white woman is such a powerful trangression that it creates a potential 'field of horror', as in the case of Payakan (Ibid, 1995). Thus, sexual interest in the 'exotic other' in the form of a Cashinahua or other indigenous man could provide an exciting and effective snub to the official mythology of the powers-that-be. Since the activists, who matured politically during the years of the dictatorship, were steeped in officially promulgated nationalist discourse, it seems possible that such meanings may be attached to their love affairs.

Whether this is the case or not, it is certainly true that indigenous men have learnt that sex with urban whites is possible Indian men are often fascinated with the idea of sexual adventures with white women. In some cases this leads to hopeless and unrequited expressions of love. In others it has lead to affairs. I am at present aware of only two indian male/White female marriages, both between relatively well-off indian men and poorer whites. In the opposite direction, white male/Indian female, two such unions have occurred to my knowledge, in these cases between Acreano pro-Indian activist and indigenous women. For the rest, short-term amorous liasons are more common. This has led to a sexualization of the space of interaction between whites and indians.

As certain leaders have grown successful and more prosperous in the urban political field since 1980, so has their use of sexuality changed. For example, in the UNI-Acre offices reference to women and female sexuality was a continuous part of daily banter amongst the organization's directors, all male leaders from different indigenous nations (though not Cashinahua). Many of these men had white lovers, or a succession of them, and (it was alleged frequent) relationships with prostitutes. Most also had wives back home in their villages (although some brought their wives to Rio Branco). In general, this kind of banter seems most marked among indigenous 
men who are successful in the urban context. These tend to be the new generation of village leaders who spend much of their time engaged in indigenous politics in the city and who have been relatively successful in capturing resources for their NGO.

In the case of others (amongst whom Cashinahua men are the majority), some of the younger generation of leaders also had sexual relationships with whites, some of these with activists of middle class background, generally from other areas of Brazil such as Rio de Janeiro. In other cases, some Cashinahua women alleged that young men had frequented local prostitutes. One year, I was told, all the young trainee teachers had returned home to their villages with venereal infections acquired in local brothels. The Casa do Indio was located near to a cheap brothel facilitating access for its temporary residents.

In these cases the sexual relations between whites and indians take place in a context where the financial power and urban cultural competence of the indians is at a far lower level than that of the whites. Unlike the few successful leaders based at UNI, these men are treading on difficult ground. Correlated with this, one rarely heard the sexual banter common in the UNI offices. Nevertheless, it is fair to say that in between 1983 and 1991 the tone of interaction between indigenous men and activist women has become more openly sexualized. This might be directly a result of the sexual activities of some white female activists which became common knowledge, but also of course of increased competence in the Brazilian culture of romance and sexuality on the part of young men concerned.

Let me illustrate this point with an anecdote. Among the first Cashinahua that I met was a young man who could barely speak Portuguese and had been brought up far from any white settlement. His relationship to me according to our true names was that of elder sister to younger brother. Thus we addressed each other and so we behaved over many years. In 1990 we met again, this time in Rio Bran- 
co where he and other colleagues were returning once again to further train as barefoot doctors. This time he and the others of his name category refused to address me as sister. Instead they insisted on calling me xanu, which can be glossed as a man's potential marriage partner and female cross-cousin. A 'xanu' is a txai's sister. No longer restricted to friendly but asexual conversation, my old friend and his colleagues enjoyed the potential for sexual banter that this recategorization afforded. This was especially so as I was competent enough in Cashinahua to be familiar with sallies and responses in the bantering between xanus and their txaitans (potential husband/male cross cousin).

I myself was puzzled and vaguely disturbed by this development. On the one hand I knew that for my friend it was a liberation from a categorical relationship that had been created by his village male leader (who named all incoming white women so that they were all his xanus and thus always my barefoot doctor friend's sisters). But on the other hand this new chapter in our relationship had to be seen in terms of the increasing potential sexualization of male indian/female white relationships. This in turn could only be seen in terms of the power relationships that were so strongly marked between these groups of people. It was for this reason, I suspect, that I found it disturbing.

\section{Conclusion}

To be a Brazilian indian, to a person belonging to an indigenous people in Acre, involves a number of social and symbolic processes. It could be a political game, where the identity is used as in a mirror held up so that the Brazilian state sees the image it would want to create of 'Brazilian indianness'. Here the identity is merely a tool for the defence of rights to land. To be a Brazilian indian might also be to make a personal transition from ignorant rural dweller to a person savvy in urban mores. Here the subject can be released from the stigma attached 
by the Cariú system of prejudices where 'Caboclo' or 'Indian' is ignorant, savage, pagan and to be discriminated against. Here, being a Brazilian indian allows the object of such prejudices to supercede them - to know himself for what he is and to defend his and his people's rights against them - ethnogenesis if you like. It might even be expressed in terms of masculine sexuality triumphant in non-Indian contexts. To be a Brazilian indian means a continued recognition of social separation from whites - in particular kinship distance is maintained even where relations are expressed in terms of possible affinity, as in the 'Txai' complex. Above all, to be a Brazilian indian is a peculiarly male activity; women continue at home being human beings whilst men play these deadly serious games in other spaces.

To be a Brazilian indian might also mean to rediscover one's own people's cultural worth, even if this becomes expressed in terms of 'Folklore' and 'Tradition'. The message can be taken back from city to village. It is here that indigenous and non-indigenous concepts of identity meet briefly: In the Brazilian mainstream culture, the formative influence on the pro-Indian activists that I have discussed, 'Brazilian indians' belong to a complex category of romantic and exotic Other. They are the perfect allies of Nature and the natural enemies of the interfering state. Yet they are also the 'original Brazilians', linking the nation with its primitive past. For the pro-Indian activists they also belong to a special category of the oppressed, doubly legitimated in their fight for their rights by their culture and traditions. So to be a 'Brazilian indian' for them is to fight for indigenous political rights and tradition - but to do so as thoroughly 'Brazilianized' beings. Here Brazilianization takes several forms: as fluent and literate speakers of the Portuguese language; as competent in the intellectual forms of rationalism and positivism; and as sexualized beings no longer beyond contemplation as partners for white women. And just as for the Cashinahua a 'Brazilian indian' is by definition male by gender. But whilst for the Cashinahua their own women stand at 
the heart of the social process, for the activists indian women stand outside it. They are the homemakers and the guardians of tradition, not actors in the modern world.

Sexual attractions between Brazilian indians and white women subvert, as I have argued, a taboo lying at the centre of Brazilian nationalism and the political ideology of the right in Brazil. This makes sense, I would suggest, in that the identity of the activists is forged not only out of the opposition between indian and white, but also out of the differences between oppressor and defender of the oppressed, state and people ('povo'), military and civil, patriarchal traditionalist and democratic liberal, old generation and new and so on. The activists not only seek to create a space and identity for the Brazilian indians, but also to make for themselves a separate identity subverting the dominant conventions of Brazilian society. In this they are at least partially successful.

\section{Notes}

1 I would like to thank the ESRC of Great Britain for funding my doctoral research in Acre (1983-1985); the Nuffield foundation for a grant allowing a return visit in 1990; and finally the Leverhulme Foundation for financing my last stay during 1991-1992. This paper was presented in an earlier version at the 1994 ABA (Associação Brasileira de Antropologia) held at Niteroi. I should like to thank Livio Sansone and all those who participated in the discussion. I am also grateful to two anonymous readers and the editors of the Revista. Special thanks go to Margaret Willson for commenting on the paper. My chief debt is to those people in Acre who helped me so kindly during my many visits. The useual disclaimers apply.

2 Carneiro de Cunha, 1978; Viveiros de Castro, 1986 \& 1992; Overing, 1983-4; Viveiros de Castro \& Carneiro de Cunha, 1993.

3 e.g. Todorov, 1984; Taussig, 1986.

4 Fabian, 1983; Said, 1978; Torgovnick, 1990; Willson, 1995; Haraway, 
1989. See also Strathern, 1988 and MacCormack \& Strathern, 1980 for deconstruction of the relationship between concepts of gender and power.

5 Or indeed their own sexual experiences in the field. But see Kulick and Willson, 1995. For the record, I have never had an affair with a Cashinahua person and spent the entire period of fieldwork in a state of celibacy. The Cashinahua respected my decision.

6 Ideally the ethnographic discussion of the Brazilians should have equal weight in the analysis. However, this has not proved possible. Whilst the analysis of the Cashinahua is based on over two years of fieldwork, and is the subject of a doctoral dissertation, I cannot boast a similar quality of research among the pro-Indian activists and other non-indigenous peoples. This is why I qualify the data on them as 'ethnographic comments'. Nevertheless, I have been familiar with their work since 1983 and count among them many friends and acquaintances. 'Participant observation' was thus highly informal during many years, when I stayed in their houses and took part in their social life whilst 'off-duty' from the indigenous research. Formally, I participated in assessment exercises of indigenous schools on the Jordão and Purus rivers, cooperated at various stages in discussions of their activities and spent some months observing CPI classes and other activities in Rio Branco.

7 Arnt and Schwartzman, 1992 contains a short history of the land question in Acre, including a discussion of some of the NGOs.

8 For discussion of these figures see CEDEPLAR 1979; Bakx 1986; McCallum 1989 \& 1990 on the Cashinahua.

9 This is a very abbreviated version of Acreano history, which is documented elsewhere. See Tocantins, 1979 for a political history; Aquino 1977 for a focus on the indigenous population; McCallum, 1989 on the Cashinahua. See Bakx, 1986 for a detailed history of "peasant formation" in the state of Acre.

10 The political history of indigenous areas in Acre witnessed a turbulent period during the 1970s. For example, when the Upper Purus Indigenous 
Area was created a number of Cariú were asked to leave and promised compensation. Although the process did not lead to violence, Cariú informants say it was very close. They laid the blame not so much upon the Indians as upon outsiders, including representatives of FUNAI and CIMI workers who were active in the area stimulating inter-indigenous political action to secure rights to land. A similar story was repeated elsewhere in Acre, as outsiders helped Indians to organize their defence of rights to land. At the same time indigenous cooperatives were set up by the Indians to comercialize rubber and handicrafts and to buy goods for sale in the communities at reasonable prices, thus breaking the monopoly of white bosses. These coops were unsuccessful financially and depended on periodic injections of capital from outside. However, they served a useful purpose in breaking the hold that Cariú bosses had had upon the Indians. This in turn has allowed the Indians in remoter areas to withdraw from further contact with the Cariú. Thus during the 1980s in areas like the Jordão monolingualism amongst children in Cashinahua was on the increase (McCallum 1990).

11 Dr.Marcos Pellegrini p.c.

12 Kensinger p.c.

13 See Arnt \& Schwartzman, 1992; McCallum, nda \& 1995.

14 Recent studies of indigenous visions of history and of 'whites' include Gow, 1991; Albert \& Ramos, forthcoming; Hill, 1988; Viveiros de Castro \& Carneiro da Cunha, 1993.

15 McCallum Forthcoming a deals with Cashinahua theories of history and concepts about 'Whites' at greater length.

16 See Overing, 1983-84 \& 1993. Also Viveiros de Castro, 1986 \& 1992; Lima, 1995 for example.

17 See also McCallum, 1990. 
18 For much more on this see also Kensinger, 1984; d'Ans, 1983.

19 If men addressed strange women at all they would call "elder sister" txipi, I was told.

20 See Skidmore, 1974; McCallum, 1995 \& nda.

21 See also Ramos, 1991 on the romantic image of the Indian in indigenism.

22 In what follows I shall use 'white' and 'indian' in imitation of racial categorization in the context discussed. I do not mean to imply any racial content to these terms, using them in a descriptive sense rather than an analytical one. In practice, 'indian' refers to a wide variety of indigenous peoples, just as 'white' refers to many different phenotypes, including in some contexts negroid or indigenous American.

23 In my own case, I was accused by the director of the programme of acting as a 'gringa imperialist'. My anthropological activities were at once based on cultural conservatism and aimed at 'stealing data belonging to the Indians'. Interestingly, these accusations were made at a time when I was attempting to formally research the relationship between pro-Indians and the Cashinahua.

24 The CPI stimulated the creation of a native literature (transcribed mythology) and encouraged the young men to research their own culture's traditions. More advanced textbooks on "geography" or "science" were constructed in Rio Branco jointly with the student teachers, so that they would be properly adapted to the indigenous pupils back home, culturally as well as intellectually. Unfortunately, despite the best of intentions, such "cartilhas" tend to infantilize and banalize Indian culture. Thus their illustrations (by Indian artists) belong at best to a Western primitivist tradition, whilst snatches of religious thinking acquire the tone of folkloric anecdote - the idea that the cosmos is composed of multiple layers, for example, sits strangely alongside a lesson on the formation of rainclouds. Be this as it may, the CPI's courses are received enthusiastically by the Indian teachers. From their point-of-view the information provided is very 
important and the education programme answers felt needs. In discussion with me about the courses, certain Cashinahua student teachers expressed enthusiasm and emphasised the need to support an expanded programme. In this way the activists' and the students' aims to some extent coincide.

25 I am reminded of Chaui's (1989) comments on the folklorization of popular culture as part of the essentialization of the concept of the Brazilian nation.

\section{Bibliography}

ALBERT, B. \& RAMOS, A. (eds.)

Forthcoming Pacificando o branco: Cosmologia, historia e politica do contato no norte da Amazonia, Brasilia, Paris, ORSTOM.

AQUINO, T.V. de

1977 Kaxinawá: de seringueiro "caboclo” a peão acreano, M.A. Thesis, Univ. de Brasilia.

ARNT, R. \& SCHWARTZMAN, S.

1992 Um artifício organico: Transição na Amazônia e Ambientalismo (19851990), Rio de Janeiro, Rocco.

BAKX, K.

1986 Peasant formation and capitalist development: The case of Acre, Southwest Amazonia, PhD. Liverpool.

CARNEIRO DA CUNHA, M.

1978 Os mortos e os outros: uma análise do sistema funerário e da noção da pessoa entre os Indios Krahó, SP, Hucitec. 
Cecília McCallum. Eating with Txai, eating like Txai

CHAUí, M.

1989 Conformismo e Resistencia, São Paulo, Brasiliense.

\section{CEDEPLAR}

1979 Migrações internas na região norte: o caso do Acre, Belo Horizonte, UFMG.

D'ANS, A.

1983 "Parentesco y nombre: Semantica de las denominaciones interpersonales Cashinahua (Pano)", in A. CORBERA (ed.) Educacion y Linguistica en la Amazonia Peruana, Lima,CAAAP.

GOW, P.

1991 Of mixed blood: Kinship and history in Peruvian Amazonia, Oxford, Clarendon.

FABIAN, J.

1983 Time and the other: How anthropology makes its object, New York, Columbia University Press.

HARAWAY, D.

1989 Primate visions: Gender, race and nature in the world of modern science, New York/London, Routledge 7.

HILL, J. (ed.)

1988 Rethinking history and myth, Urbana, U. of Illinois P.

KENSINGER, K.

1984 "An emic model of Cashinahua marriage", in KENSINGER, K. (ed.) Marriage practices in lowland South America, Urbana \& Chicago, Univ. of Illinois P.

KULICK, D. \& WILLSON, M. (eds.)

1995 Taboo, New York/London, Routledge. 
LIMA, T. S.

1995 A parte do Cauim: Etnografia Juruna, $\mathrm{PhD}$ thesis, Rio de Janeiro, Museu Nacional.

MACCORMACK, C. \& M.STRATHERN (eds.).

1980 Nature, culture and gender, Cambridge, CUP.

MCCALLUM, C.

1989 Gender, personhood and social organization among the Cashinahua of Western Amazonia, PhD thesis, London School of Economics.

1990 "Language, kinship and politics in Amazonia", Man (N.S.) 25:412-433.

1995 "The Veja Payakan: the media, modernism and the image of the Indian in Brazil", CVA Newsletter, Bulletin de la Commission d'anthropologie visuelle, Denmark.

in press "The body that knows: From Cashinahua epistemology to a medical anthropology of lowland South America", Medical Anthropology Quarterly.

forthcoming a. "Os Incas e os Nawas: Produção, transformação e transcendencia na história Kaxinaua", in Albert, B. and Ramos, A. (eds.)

forthcoming $b$. "The acquisition of gender and the skills of production: the Cashinahua case", Cadernos PAGU (to be published translated in Portuguese).

nda. Gender symbolism in Brazil: Amazonia and the Nation's Future, paper presented at the symposium The politics of contact and anthropological thinking, Annual Meeting of the American Anthropological Association, New Orleans, 1990.

OVERING, J.

1983-4 "Elementary structures of reciprocity: a comparative analysis of Guianese, Central Brazilian and Northwest Amazon socio-political thought", in COLSON, A.B. \& HEINEN, H.B (eds.) Themes in Political Organization: the Caribs and their neighbours - Antropologica, vols.59-62, Fundacion La Salle, Caracas.

1993 "Death and the loss of civilized predation among the Piaroa of the Orinoco basin”, L'Homme 126-128, XXXIII (2-4):191-211. 


\section{RAMOS, A.}

1991 "A hall of mirrors: The rhetoric of indigenism in Brazil", Critique of Anthropology, v.11 (2):155-69.

ROCHA, E.P.G.

1984 "Um Índio didático: Notas para o estudo de representações", in ROCHA, E.P.G. (et al) orgs. Testemunho ocular, São Paulo.

SAID, E.

1978 Orientalism, New York, Pantheon.

SKIDMORE, T. E.

1974 From black into white: Race and nationality in Brazilian thought, New York, Oxford UP.

TAUSSIG, $\mathrm{M}$.

1986 Shamanism, colonialism and the wild man: A study in terror and healing, Chicago U.P.

TOCANTINS, L.

1979 Formação histórico do Acre, vols I \& II, Civilização Brasileira.

n.d.a. $O$ Acre, Rio Branco.

TODOROV, T.

1984 The conquest of America, New York, Harper.

TORGOVNICK, M.

1990 Primitive: Savage intellects, modern lives, Chicago, UP.

VIVEIROS DE CASTRO, E.

1986 Arawete os deuses canibais, Rio de Janeiro, Zahar/ANPOCS.

1992 From the enemy's point-of-view: Humanity and divinity in an Amazonian society, Chicago, UP. 
Revista de Antropologia, São Paulo, USP, 1997, v. 40 nº1.

VIVEIROS DE CASTRO, E. \& CARNEIRO DA CUNHA. M. (eds.)

1993 Amazônia: Etnologia e história indígena, São Paulo, NHII/USP-FAPESP.

WILLSON, M.

1995 "Afterword: Perspective and difference: sexualization, the field and the ethnographer", in Kulick, D. \& Willson, M. (eds.).

\begin{abstract}
This paper discusses constructions of social identity as 'Brazilian indian' in Acre between 1983 and 1991. It focuses on the Cashinahua in their relations with pro-Indian support organizations, examining how concepts and practices producing sociality were employed or negated in this social context. To do so, the paper outlines the form interethnic relations took in the region. It relates inequality in the sociopolitical context to changes in gender constructs and sexuality in interethnic situations.
\end{abstract}

KEY WORDS: Inter-ethnic relations, sociality, sexuality, gender, nongovernmental organizations, Cashinahua, Amazonia, Brazil. 
Cecília McCallum. Eating with Txai, eating like Txai 